\title{
In Vitro Propagation of Rhodohypoxis baurii
}

\section{S.J. Upfold, J. van Staden, and T.J. Edwards}

University of Natal/Foundation for Research Development, Research Unit for Plant Growth and Development, Department of Botany, University of Natal, P.O. Box 375, Pietermaritzburg 3200, Republic of South Africa

Additional index words. micropropagation, corm

Rhodohypoxis is a genus of the Hypoxidaceae endemic to South Africa. Characteristically, the plants are small cormous herbs growing at high altitudes (1990-3200 m) in the Natal Drakensberg. The most recent classification recognizes six species (Hilliard and Burtt, 1978). Three varieties of Rhodohypoxis baurii (Baker) Nel were collected on a damp grassy cliff $\approx 2400 \mathrm{~m}$ above sea level in Giant's Castle Nature Reserve. These small, high-altitude plants have a long flowering period (October-February), and their flowers are very attractive (Fig. 1). The pink and red varieties are rare in nature. These plants would be ideally suited as pot plants as they grow well under warm conditions and flourish in a greenhouse environment. As these plants are suited for domestication, we investigated the possibility of rapid multiplication by in vitro techniques.

Small corms ( 0.5 to $0.8 \mathrm{~cm}$ in diameter) were lifted from the soil, all roots removed, and washed thoroughly in running tap water for $5 \mathrm{~min}$. The corms were then scrubbed gently to remove remaining soil particles and surface sterilized by soaking in $80 \%$ ethanol for $5 \mathrm{~min}$, followed by immersion in $0.1 \%$ $\mathrm{HgCl}_{2}$ containing a few drops of Tween 20 for $10 \mathrm{~min}$. After being rinsed three times in sterile distilled water, each corm was cut longitudinally into four sections. Twenty sections from five corms of each variety were used. Each section was transferred into a 25 $\times 90$-mm culture tube containing $10 \mathrm{ml} \mathrm{Mu}-$ rashige and Skoog (1962) medium (MS) solidified with $1 \%$ Unilab agar and amended with $30 \mathrm{~g}$ sucrose and $0.1 \mathrm{~g}$ myo- inositol/ liter. The $\mathrm{pH}$ was adjusted to 5.8 with 0.1 $\mathrm{M} \mathrm{NaOH}$ before autoclaving. Cultures were maintained under constant light of 16.2 $\mu \mathrm{mol} \cdot \mathrm{m}^{-2} \cdot \mathrm{s}^{-1}$ provided by cool-white fluorescent tubes at $24 \pm 1 \mathrm{C}$. Explants were incubated on the MS medium for 4 weeks, whereafter they were subcultured successively onto media containing various growth regulators and vitamin supplements. Twenty replicates per treatment were used. Treatments consisted of either a combination of $5.37 \mu \mathrm{M}$ 1-naphthaleneacetic acid (NAA) and

Received for publication 2 Dec. 1991. Accepted for publication 23 Apr. 1992. Supported by grants from the Foundation for Research Development and the University of Natal Research Fund. The cost of publishing this paper was defrayed in part by the payment of page charges. Under postal regulations, this paper therefore must be hereby marked advertisement solely to indicate this fact.
$4.65 \mu \mathrm{M} \mathrm{N} \mathrm{N}^{6}$-furfurylaminopurine (kinetin); a combination of $5.37 \mu \mathrm{M}$ NAA, $4.65 \mu \mathrm{M}$ kinetin, and $2.96 \mu \mathrm{M}$ thiamine; or only 2.96 $\mu \mathrm{M}$ thiamine. Regenerated 7-week-old cormlets were washed to remove the agar, and then planted into pots containing a 1 sterile sand : 1 peat $(\mathrm{v} / \mathrm{v})$ mixture for hardening off. The plants were maintained under intermittent mist for 2 weeks at 30C under daylight conditions and then transferred to a greenhouse where they were watered weekly.

The sterilization technique used was very successful, and all explants remained free of contaminating organisms. Multiple shoots developed on all the explants on MS without growth regulators within 2 weeks (Fig. 2A). The red R. baurii var. baurii produced the most shoots (Table 1). Roots developed on the newly formed shoots after 4 weeks (Fig. 2B). With each subculture onto MS medium, the newly formed cormlets produced more shoots throughout the year. Explants from pink and white forms of $R$. baurii var. platypetala formed half as many or fewer shoots than the red ones (Table 1). Additionally, the former died back during winter, despite explants being maintained in a growth room. This cessation of growth coincided with the end of the flowering period of stock plants maintained in the greenhouse and with the onset of winter dormancy. The red-flowering variety did not display this endogenous rhythm. They did, however, cease multiplication if not subcultured regularly. Attempts to increase the multiplication rate of the pink and white varieties over that of the control (MS without growth regulators) by including various combinations of $5.37 \mu \mathrm{M}$ NAA, 4.65 $\mu \mathrm{M}$ kinetic, and $2.96 \mu \mathrm{M}$ thiamine were unsuccessful (data not shown).

Of the 7-week-old daughter plants, $90 \%$ survived the hardening-off process. They continued to produce new shoots in the soil and flowered in the 2nd year of growth. From the in vitro results and the physiological behavior of the three varieties investigated, it is clear that these plants can easily be domesticated. However, there are indications

Table 1. Shoot and root production per explant for three varieties of Rhodohypoxis baurii after 4 weeks in culture.

\begin{tabular}{lcc}
\hline \hline $\begin{array}{l}\text { Flower } \\
\text { color }\end{array}$ & $\begin{array}{c}\text { Shoots/ } \\
\text { tube (no.) }\end{array}$ & $\begin{array}{c}\text { Roots/ } \\
\text { shoot (no.) }\end{array}$ \\
\hline White & $2.8+1.1$ & $2.5 \pm 0.6$ \\
Pink & $3.8 \pm 1.3$ & $2.8 \pm 1.5$ \\
Red & $7.5 \pm 1.7$ & $3.1 \pm 0.7$ \\
\hline
\end{tabular}

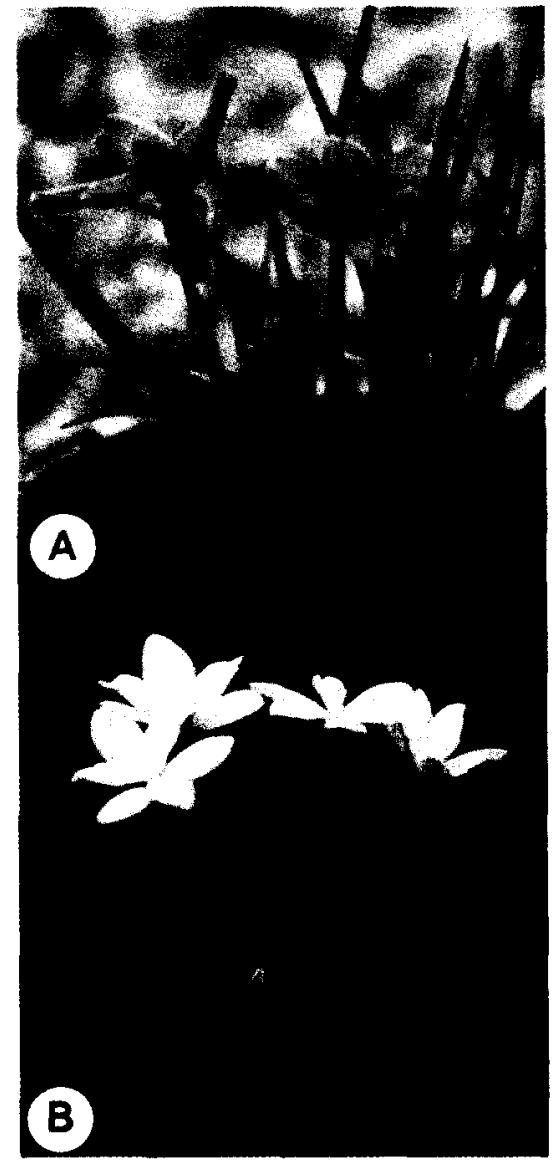

Fig. 1. (A) Rhodohypoxis baurii var. baurii $(\times 1.17)$ and $($ B) $R$. baurii var. platypetala $(\times 0.67)$ in flower. The plants are $\approx 7.5 \mathrm{~cm}$ tall.
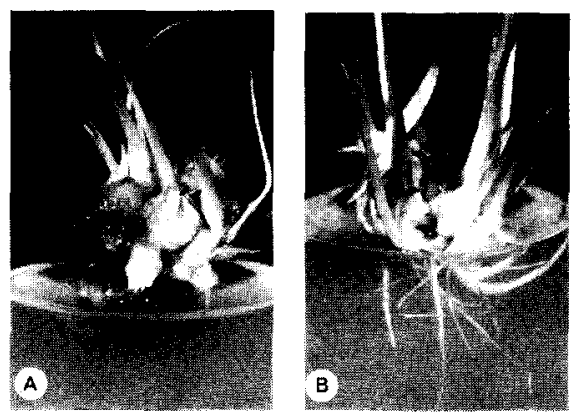

Fig. 2. Multiple shoot (A) and root (B) formation on explants of Rhodohypoxis baurii var. baurii after 2 and 4 weeks of culture on MS medium in the absence of growth regulators (x 2.27).

that the classification of this particular species should be reinvestigated, as there were distinct similarities between the pink and white forms and differences between these two forms and the red variety.

\section{Literature Cited}

Hilliard, O.M. and B.L. Burtt. 1978. Notes on some plants from Southern Africa chiefly from Natal, VII. Notes from the Royal Botanic Garden, Edinburgh 36:43-76.

Murashige, T. and F. Skoog. 1962. A revised medium for rapid growth and bioassays with tobacco tissue cultures. Physiol. Plant. 15:473-497. 